\title{
Yolsuzluk Muhasebesi: GRI 205 Standardı Özelinde Normatif Bir Araştırma (Corruption Accounting: A Normative Research Based on the GRI 205 Standard)
}

\author{
Soner GÖKTEN iD a Pinar OKAN GÖKTEN iD b \\ a Başkent Üniversitesi, İktisadi ve İdari Bilimler Fakültesi, İşletme Bölümü, Ankara, Türkiye. sgokten@baskent.edu.tr \\ b Ankara Hacı Bayram Veli Üniversitesi, İktisadi ve İdari Bilimler Fakültesi, Uluslararası Ticaret ve Finansman Bölümü, Ankara, \\ Türkiye.pinar.okan@hbv.edu.tr
}

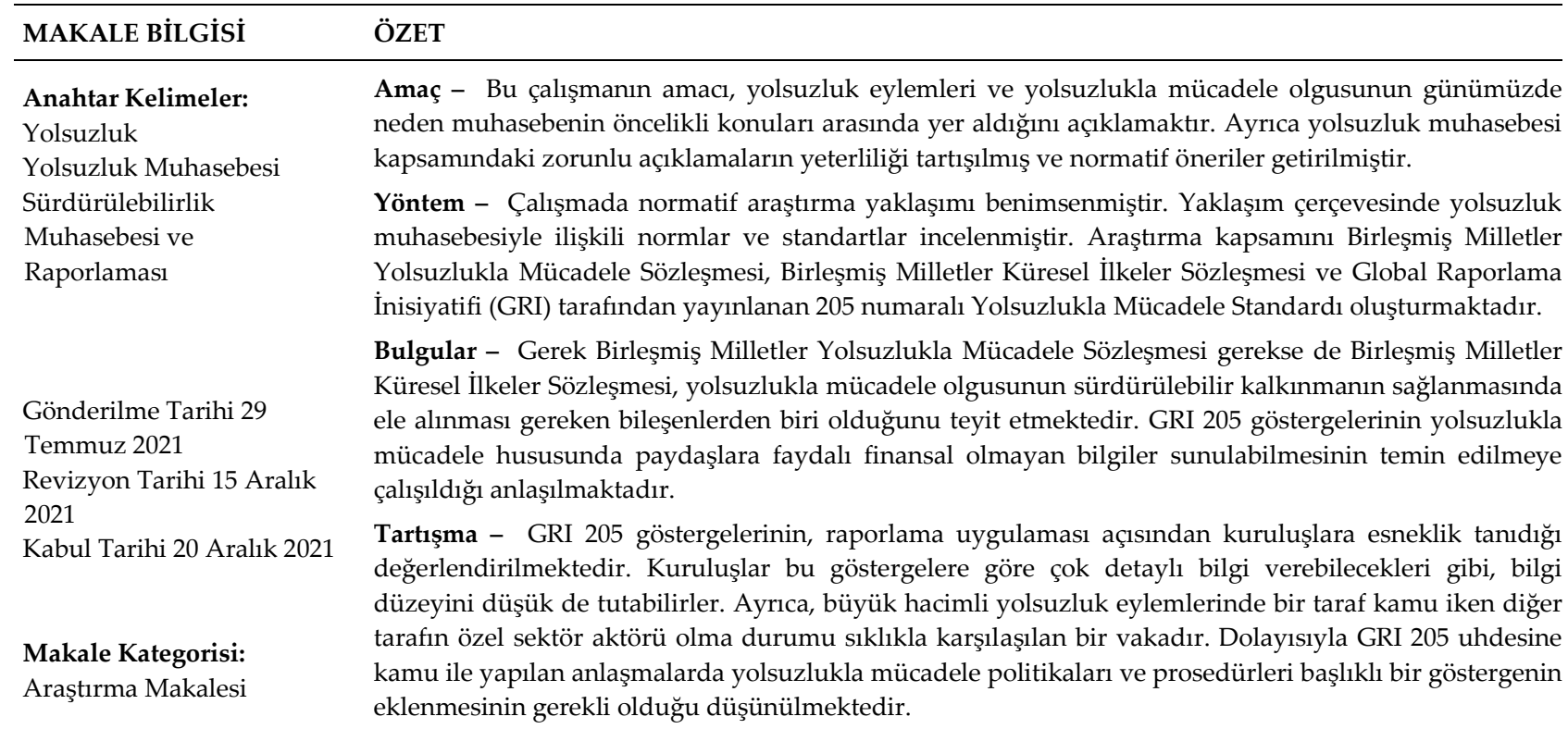

\begin{tabular}{l}
\hline ARTICLE INFO \\
\hline Keywords: \\
Corruption \\
Corruption Accounting \\
Sustainability Accounting \\
and Reporting
\end{tabular}

Received 29 July 2021 Revised 15 December 2021 Accepted 20 December 2021

\section{ABSTRACT}

Purpose - The aim of this study is to explain why acts of corruption and the fight against corruption are among the priority issues of accounting today. In addition, the adequacy of mandatory disclosures within the scope of corruption accounting was discussed and normative suggestions were made.

Design/Method/Approach - The normative research approach was adopted in this study. Within the framework of the approach, norms and standards related to corruption accounting were examined. The scope of the research is the United Nations Convention against Corruption, United Nations Global Compact and the Anti-Corruption Standard 205 published by the Global Reporting Initiative (GRI).

Findings - Both the United Nations Anti-Corruption Convention and the United Nations Global Compact confirm that the fight against corruption is one of the components that should be addressed in ensuring sustainable development. It is understood that efforts are made to ensure that the GRI 205 indicators provide useful non-financial information to stakeholders on the fight against corruption.

Discussion - GRI 205 indicators are considered to provide flexibility to organizations in terms of reporting practice. Organizations can provide very detailed information based on these indicators, or they can keep the level of knowledge low. In addition, in large-scale corruption acts, it is a frequent case that while one party is public sector, the other one is a private sector actor. Therefore, it is considered necessary to include an indicator titled anti-corruption policies and procedures in agreements with the public sector under the GRI 205.

Article Classification: Research Article 


\section{Giriş}

9 Aralık 2020 Uluslararası Yolsuzlukla Mücadele Günü'nde Birleşmiş Milletler tarafından paylaşılan verilere göre, her yıl küresel düzeyde verilen rüşvet miktarı 1 trilyon dolar iken tahmini yolsuzluk tutarı ise 2,6 trilyon dolar civarındadır. Küresel hasılanın 80 milyar dolar olduğundan hareket edildiği takdirde açılanan bu rakamların küresel hasılanın yüzde beşinden daha fazla olduğu anlaşılmaktadır (Euronews, 2021).

Sahip olunan yetkinin şahsi menfaatler doğrultusunda kullanılması olarak tanımlanabilen yolsuzluğun (Rodriguez ve diğerleri, 2006), günümüzde bu denli yüksek miktarlarda bahse konu bir problem teşkil etmesinin temel nedenleri arasında hiç şüphesiz ki küresel ticaret ve yatırımların olağanüstü artışı yer almaktadır (Sanyal, 2005). Yolsuzluğa neden olan ekonomik faktörler dikkate alındığında; uluslararası ticaret ve yatırım ekseninde ortaya çıkan vergi ve düzenlemelerin sebep olduğu maliyetlerden kurtulma amacı, iş yapanları rüşvet vermeye teşvik etmektedir (Besley ve McLaren, 1993). Özellikle büyük tutarlı işleri içeren, özelleştirme ve birtakım imtiyazlar yoluyla özel işletmelere ciddi mali fayda sağlayan ve çok yönlü çıkar gruplarının yer aldığı projeleri yöneten ve kontrol eden, buna karşın yönettikleri işle mukayese edildiğinde maaşları düşük olan kamu görevlerinin rüşvet istemeye ve almaya yatkınlıklarının olması muhtemeldir (Rijckegham ve Weder, 1997).

Yolsuzluğun durumunu belirleyen diğer bir etmen ise insanların değerlerini, bakış açısını ve davranışlarını çerçeveleyen kültürel etmenlerdir (Ronen ve Shenkar, 1985). Bir toplumun birliğini tesis eden ve gelenek özelliği taşıyan soyut varlıkların (düşünce şekli, davranış biçimi vb.) tümü ülkelerin kendilerine has kültürel farklılıklarını tesis eder. Bu açıdan kültür; toplumların zenginlik, adalet, değişim, rekabet gibi kavramlara karşı bakış açılarını, hassasiyetlerini ve tepkilerini şekillendirir. Hiç şüphesiz ki, insan davranışlarında iyi ya da kötü veya doğru ya da yanlış olarak adlandırılan değer yargılarının bütününü kapsayan ahlak, yolsuzluk üzerindeki kültürel etkinin ortaya çıkışında başrolü oynar. Bu bakımdan insani davranışların ahlaki tarafı üzerine odaklanan ahlak felsefesinin toplumların yolsuzluk ile kültürel vaziyetleri arasındaki ilişkinin incelemesinde önemli bir yeri vardır. Örneğin Morishima (1982), Japon kamu görevlilerinin Konfüçü̈s ahlakını benimsediklerini iddia etmiştir. Konfüçyüs ahlakı şöyle der (Aktan, 2001:20): ‘Hiç erişemeyecekmişsin ya da yitirecekmişsin gibi çalış'. Konfüçyüs, çalışma ahlakının önemi üzerinde duran düşünürlerin başında gelir. Konfüçyüs'e göre çalışma, mutluluğa ve refaha ulaşmanın yoludur. Bu bağlamda, Japon kamu görevlilerinin çalışma anlayışlarında refah ve mutluluğu maddi sonuçlar itibariyle değil işlerini iyi yapma çerçevesinde ele aldıkları, bu nedenle de yolsuzluğa yatkınlıklarının yüksek olmadığı söylenebilir. Kültürel olarak bu yönlü bir çalışma ahlakının mevcudiyeti hiç şüphesiz ki vuku bulan yolsuzluk olaylarına karşı toplumun sert şekilde vereceği eleştirel ve sert tepkileri ortaya çıkaracaktır. Tersi durumda, yani kısaca yozlaşmış ve ahlaki değerlerin görmezden gelindiği toplumlarda vuku bulan yolsuzluklara karşı kulak arkası etme ve kabullenme eğilimleri söz konusu olabilir.

Ahlak kuralları yazılı değildir ve resmi olarak yaptırım içermezken, hukuk resmi ve yazılı ahlak kuralları olarak ifade edilebilir. Hukukun ahlaktan en belirgin farkı resmi yaptırımlar (cezalar) içermesidir. Bu açıdan yolsuzluğun durumu üzerinde hukuk önemli bir etki faktörü olarak dikkate alınır. ABD, 1997 yılında yabancı ülkelerin kamu görevlilerine rüşvet teklif edilmesini yasa dışı eylem haline getiren dünyadaki ilk ülkedir (Cragg ve Woof, 2002). Takip eden süreçte ise tüm dünyada yolsuzluk eylemlerindeki ve bunların sonucunda karşılaşılan ekonomik hasarlardaki artışa karşı uluslararası düzeyde yolsuzluk eylemlerinin birer suç olarak tanımlanması temin edilmiş ve günümüz itibariyle neredeyse tüm ülkeler kendi iç hukuk sistemlerinde yolsuzluk eylemlerini birer suç olarak tanımlayan düzenlemeleri hayata geçirmişlerdir.

Uluslararası yatırım ve ticaretteki artış, toplumsal ahlak, norm ve değerler ile resmi hukuk kuralları bir arada ele alındığında yolsuzluk eylemelerinin nedenleri ve bu eylemlerin önlenmesine yönelik araçların ne denli çok yönlü ve çok faktörlü olduğu açıktır. Bununla birlikte günümüzdeki iletişim araçları ve teknolojisi sayesinde dünyanın yolsuzlukla mücadele konusunda geçmişten daha avantajlı durumda olduğu açıtır. Elde edilen büyük veriler ve bildirimler yolsuzlukla mücadelede risklerin erken saptanması ve takip edilmesi açısından kuruluşlara ciddi imkan ve kabiliyet sağlamaktadır. Dolayısıyla günümüzde kuruluşların yolsuzluk eylemlerini ve yolsuzlukla mücadele yaklaşımlarını paydaşlarına iletebilme kabiliyetleri ve imkanı artmıştır.

Bu çalışmada yolsuzluk eylemleri ve yolsuzlukla mücadele olgusunun neden muhasebenin öncelikli konuları arasında yer aldığı ve Global Raporlama İnisiyatifi (GRI) özelinde kuruluşların yolsuzluk muhasebesi kapsamında yapmaları gereken açıklamalar, normatif araştırma bakış açısıyla irdelenmektedir. Araştırmada 


\section{S. Gökten - P. Okan Gökten 13/4 (2021) 3701-3711}

kuruluşlar tarafından yapılacak yolsuzluk muhasebesi uygulamalarının ve raporlamaların yolsuzlukla mücadele çerçevesinde en önemli araçlardan biri olduğu iddia edilmektedir. Bu bahisle yolsuzluk eylemeleri ve yolsuzlukla mücadele konusu özelinde sürdürülebilirlik raporlamasında sunulması gereken açılamalar incelenmiş ve yolsuzluk muhasebesinin toplumsal katkısı değerlendirilmiştir.

Çalışmanın takip eden bölümünde, yolsuzluk kavramının kuramsal boyutu ve kurumsallaşma süreci olmak üzere kavramsal çerçevesi açıklanmıştır. Üçüncü bölümde çalışmanın yöntemi, amacı ve normatif araştırma kaynakları belirtilmiştir. Bulgular dördüncü bölümde açılanmış olup, çalışma beşinci bölümde normatif önerileri de içeren sonuç ve tartışma ile sonlandırılmıştır.

\section{Kavramsal Çerçeve}

Yolsuzluk iki boyut itibariyle literatürde geçen ve ekonomi başta gelmek olmak sosyal bilimlerin araştırma alanı içerisinde sıklıkla yer bulan kavramlardan biridir. Birinci boyut yolsuzluk kavramının anlamıdır. Özellikle ekonomik etkileri dikkate alındığında, yolsuzluk kavramı çok yönlü bakış açılarını içermektedir. Diğer bir boyut ise yolsuzlukla mücadelenin kurumsallaşma sürecidir. Diğer bir ifadeyle yolsuzlukla mücadeleye ilişkin norm, kural ve süreçler bütününün günümüzde geldiği durumdur.

\subsection{Yolsuzluğun Kuramsal Çerçevesi ve Yarattığı İklim}

Karar vericiler, diğer bir ifadeyle yönetsel güce haiz kişiler, toplumsal düzen ve refah için görevlerini tarafsız bir şekilde, yani kendilerinin veya yakından ilişkili olduklarının faydasını maksimize etmeyi amaçlamadan yürütmelidirler. Aksi durumda yolsuzluk ortaya çıkar. Kısaca, birden çok tarafı ilgilendiren ekonomik kararlarda kişisel veya diğer ilişkiler rol oynamamalıdır. O halde yolsuzluk, genel geçer olarak ekonomik kararlarda kendisi veya ilgili kişiler için menfaat temin etmeyi amaçlayarak emsallere uygunluk ilkesine kasıtlı olarak uyulmaması şeklinde tanımlanabilir (Tanzi, 1995).

Makro düzeyde ele alındığında yolsuzluk ile kurumsal iktisat arasında yakın bir bağıntı dikkat çeker. North ve Thomas (1973), ekonomik gelişmenin dayanağının yüksek kurum kalitesi olduğunu ifade etmektedirler. North (1981) kurumları, 'insanlar tarafından icat edilmiş ve idare gücünü elinde bulunduran bireylerin kendi refahlarını veya elde edecekleri faydaları maksimize etmelerini sınırlayan kurallar, süreçler ve normlar' olarak tanımlamaktadır. O halde kurumların (insan hakları, hukukun üstünlüğü, demokrasi vb.) kalitesi arttıkça ülkelerin ekonomik gelişmişliğinin arttığının kabulü söz konusudur. Hiç şüphesiz ki, söz konusu paradigma çerçevesinde kurum kalitesindeki artış; idare gücünü elinde bulunduran karar alıcıların iktidar güçlerini sınırlandıran, keyfiyetten uzaklaştıran ve verilmiş kararlar üzerinde denge ve kontrol yaratan kısıtları oluşturur. Bu bahisle söz konusu kısıtlar esasen yolsuzluğu engelleyici görev icra ederler. Tanzi (1995)'nin yolsuzluk tanımından yola çıkıldığında; kurum kalitesindeki artış ekonomik kararlarda emsallere uygunluk ilkesine kasıtlı olarak uyulmaması üzerinde caydırıcı etki gösterir.

Mauro (1998) ve Svensson (2005)'un belirttiği şekilde, yolsuzluğun ekonomik gelişmişliği aşağiya iten en belirgin etkilerinden biri şeffaf raporlamaya haiz olmayan ve hesap verilebilir ekonomik faaliyetler dişında kalan ekonomik faaliyetlerin hacminin artarak kamu harcamalarını ve finansmanını bozmasıdır. Kamu kaynaklarının çıkar gruplarının menfaatlerine aktarılması, kamusal malların kalitesi ve verimliliğini negatif yönde etkiler. Bu durum hiç şüphesiz ki vergi gelirlerinde azalma ve kamu finansman dengesinde büyüyen açık sorunuyla neticelenir.

Anlaşılabileceği gibi yolsuzluk unsuru kamusal organizasyonlardan bağımsız olarak ele alınamaz. Şöyle ki, özel sektörde yer alan iki taraf arasındaki ticari bir işlemde taraflar rasyonel davranacak, karşılıklı olarak çıarlarını maksimize etmek isteyecekler ve bu bağlamda yüksek ihtimalle emsallere uygunluk ilkesine bağlı kalacaklardır. Örneğin; arsasını satan ve o arsayı alan özel sektör işletmelerinin arasındaki işlemde, arsa fiyatı büyük olasılıkla piyasadaki olağan bir işlem sırasında taraflar arasında kabul edilen bir fiyatı temsil edecek, emsallere uygunluk ilkesiyle çatışmayacak ve bu işlemin negatif kamusal etkisi olmayacaktır. Lakin bu işlemde kamusal bir rol varsa durum değişebilir. Mesela taraflardan biri, belediye başkanıyla yakın bir ilişkiye haiz olabilir. Şayet belediye başkanı tarafsızlık ilkesini rafa kaldırmış ve ilgili arsanın imar planının arsanın satışı sonrası değiştirilmesi hususunda yakın ilişkili olduğu işletmeyle anlaşmaya varmış ise; arsa satış işleminde oluşan fiyat emsallere uygunluk ilkesine aykırılık teşkil eder. Öncelikle satan taraf içsel bilgiye haiz olmadığından ciddi gelir kaybına uğrar. Alan taraf elde ettiği rantı kendi zenginleşmesini sağlamak ve rüşvet kaynağı olarak kullanır. Kısacası belediye başkanı yönetsel gücünü kendi ve yakın ilişkide olduğu işletmenin 


\section{S. Gökten - P. Okan Gökten 13/4 (2021) 3701-3711}

menfaatlerini maksimize etmek için kullanmış ve servet transferi yaratarak kamusal refahı bozmuş olur. Diğer bir ifadeyle, benzer eylemi çok kez tekrarlatmış yani yakın ilişkide olduğu işletmenin çok sayıda arsayı ucuza satın almasını temin etmiş ise; diğerlerini yoksullaştırmış, kendini ve yakın ilişkide olduğu işletmeyi ise zenginleştirmiş olur. Bu durum açık bir şekilde gelir dağılımının bozulmasına hizmet etmiştir. Dolayısıyla yolsuzluğun önemli ekonomik etkilerinden biri de gelir dağılımını bozmasıdır (Jain, 2001).

Yolsuzluk eylemlerinin süreklilik arz eder şekilde vuku bulması, gelir dağılımını sürekli bozarak dezavantajlı grup olarak nitelendirilebilecek yoksulların oluşmasına neden olur. Kurumsal kalitesi çökmüş sistemlerde rüşvet kaynağına sahip olmayan yoksulların bir süre sonra kamusal söz hakları adeta ortadan kalkar ve toplum içerisindeki dezavantajlı durumları katlanarak her geçen gün daha kötüye gider (Bardhan, 1997). Dezavantajlı gruplar, yolsuzluğun avantajlı grupları hakim kılması nedeniyle ekonomik kaynaklara erişemezler ve bozulan ekonomik vaziyet nedeniyle giderek daha fazla maliyetlerle karşı karşıya kalırlar. Parasal maliyetlerin yanı sıra dezavantajlı gruplar için ortaya çıkan bürokratik gecikmeler, artan belirsizlik ve bilgiye ulaşma zorlukları onların yaşamsal kalitelerini aşağıya çeken başlıca parasal olmayan maliyetler olarak ifade edilebilir (Habib ve Zurawicki, 2002; Luo, 2011).

Sonuçları itibariyle bireylerin refah seviyesini aşağıya çeken ve hem maddi hem de manevi hak gaspı yaratan yolsuzluk eylemlerinin neden olduğu ekonomik ve sosyal iklim; beşeri sermaye ve hukukun üstünlüğü başta olmak üzere kurumların çöküşünü beraberinde getirerek kalkınmanın durmasına yol açar. Bu nedenle yolsuzlukla mücadele günümüzde uluslararası düzeyde ele alınan ve ülkelerce süreklilik gösterir şekilde gündemi teşkil eden konuların başında gelmektedir.

\subsection{Yolsuzlukla Mücadelenin Kurumsallaşması}

Küresel bir sorun haline gelen ve giderek artan skandallar, yolsuzlukla mücadelenin uluslararası düzeyde kurumsal hale getirilmesini gerekli kılmıştır. Nitekim Birleşmiş Milletler, Uluslararası Para Fonu, Dünya Bankası, İktisadi İşbirliği ve Kalkınma Teşkilatı (OECD), Avrupa Birliği ve Avrupa Konseyi gibi organizasyonlar yolsuzlukla mücadele için çerçeve ilkeler ortaya koymakta ve bu ilkeleri benimsetmek için çalışmalar gerçekleştirmektedirler.

Yolsuzluk eylemleriyle mücadelenin uluslararası seviyede kurumsallaşmasına hizmet eden bağlayıcı ve etkin çözüm sunan yegane araç Birleşmiş Milletler Yolsuzlukla Mücadele Sözleşmesi'dir (BMYMS). 31 Ekim 2003 tarihinde Birleşmiş Milletler Genel Kurulu'nun 58/4 No'lu kararı ile kabul edilen BMYMS, 14 Aralık 2005 itibarıyla uygulamaya geçirilmiştir. Sözleşmeye taraf olan 188 ülke (11 Ağustos 2021 itibariyle; UNCAC, 2021) arasında yer alan Türkiye, 10 Aralık 2003 tarihinde sözleşmeyi imzalamış ve 24 Mayıs 2006 itibariyle Resmi Gazete'de yayımlayarak yürürlüğe koymuştur.

BMYMS'nin üçüncü bölümünde Taraf Devletlerce yolsuzluk eylemlerinin suç olarak düzenlenmesi ve diğer gerekli önlemlerin alınması hususları birer zorunluluk olarak karara bağlanmıştır. Diğer bir ifadeyle, sözleşmenin üçüncü bölümü yolsuzluğu tüm yönleriyle küresel seviyede suç olarak tanımlamış ve Taraf Devletlere kendi yasal çerçevelerinde sözleşmede belirtilen eylemleri suç olarak düzenlemeleri görevi vermiştir. BMYMS'nin 15-20. Maddeleri kamu açısından yolsuzluk eylemlerini madde sırasıyla 'ulusal kamu görevlilerinin rüşveti', 'yabancı kamu görevlilerinin ve uluslararası kamu kuruluşu görevlilerinin rüşveti', 'malvarlığının kamu görevlilerince zimmete geçirilmesi, kötüye kullanılması ya da diğer biçimlere dönüştürülmesi', 'nüfuz ticareti', 'görevi kötüye kullanma' ve 'haksız zenginleşme' olarak tanımlamıştır. 21 ve 22. Maddeler ise özel sektör açısından yolsuzluk eylemlerini madde sırasıyla 'özel sektörde rüşvet' ve 'özel sektörde zimmet' olarak tanımlamıştır.

Hiç şüphesiz ki, yolsuzluk eylemlerinin yasal çerçeveyle suç olarak tanımlanması ve ciddi cezai yaptırımlar içermesi yolsuzluğa olan yönelimi engelleyici etki yapar. Lakin yolsuzlukla mücadelenin yalın olarak yasal suç tanımlaması ve önleyici cezai yaptırımlarıyla başarıya ulaşmasının mümkün olmadığı gerçeği de yadsınamaz. Diğer bir ifadeyle, yolsuzluğun kültürel ve davranışsal boyutları ile toplumsal ahlak anlayışının durumu; yolsuzlukla mücadelede kayda değer önem taşımaktadır. Bu norm ve değerlerin oluşması ve organize edilmesi çok açıktır ki yolsuzlukla mücadelenin yasal ayağını destekleyecek ayakların inşasına katkı sunar.

Yolsuzluk skandallarının veya yolsuzluk eylemi şüphesi yaratan hadiselerin neredeyse tamamında kamu görevini üstlenenler ön plandadır. Kurumsal iktisat, kamu malı anlayışı, vergi yaklaşımı ve adaletli gelir 


\section{S. Gökten - P. Okan Gökten 13/4 (2021) 3701-3711}

paylaşımı beklentileri açılarından da yolsuzluk eylemine karışmış kamu görevlisinin skandal patlak verdiğinde vitrinde yer alması son derece olağandır. Lakin unutulmaması gereken iki boyut söz konusudur: Birincisi, söz konusu kamu görevlisinin yolsuzluk eyleminden menfaat temin etmesi için genellikle karşı bir taraf vardır ve bu taraf muhtemeldir ki özel sektör aktörlerinden birisidir. İkincisi, yolsuzluk davranışının ortaya çıkan skandalı veya şüpheye mahal veren hadiseyi ikinci plana atabilecek, görmezden geldirebilecek veya saklayacak donelerinin veya gerekçelerinin olması muhtemeldir.

Her iki boyut birlikte ele alındığında; menfaati maksimize edilen özel sektör aktörü üzerinden yolsuzluk eylemi perdelenmeye çalışılabilir veya perdelenir. Örneğin, özellikli bir inşaat ya da üretim işini üstlenen ve bunun karşıllğında emsallere uygunluk ilkesinin tam tersi yönünde maliyetin veya olması gerekenin çok üzerinde kazanç elde eden özel sektör aktörünün elde ettiği fayda, söz konusu işin ülke için gerekliliği ön plana çıkarılarak meşrulaştırılmaya çalışılabilir. Diğer bir ifadeyle, özellikli işin emsallere uygunluk ilkesinden gösterdiği sapmalar genellikle perdelenerek ikinci plana atılır.

Wolfe ve Hermanson (2004) tarafından kuramsal çerçevesi tanımlanan hile elması modeli; bir tarafı kamu ve diğer tarafı özel sektör olan yolsuzluk davranışlarını açıklayıcı bir paradigma ortaya koymaktadır. Şöyle ki, teşvik ve baskıya ek olarak kurumsal kalitesi düşük kamusal çevrede yolsuzluk davranışını yerine getirmek için gerekli olan kabiliyet ve meşrulaştırma zemini mevcuttur. Çünkü hileli eylemler ihtiva eden yolsuzluk davranışlarının yönetsel gücü elinde bulunduranlar tarafından gerçekleştirilebilmesi için kabiliyet (yönetsel gücü elinde bulunduranların karar vermede sahip olduğu güçlü yetki, zayıf iç kontrol ve müdahale edilebilir denetim vb.) unsuruna gerek vardır (Okan Gökten, 2018). Bu nedenle, hile elması modeli çerçevesinde, kurumsal kalitesi zedelenmiş veya çökmüş yönetimlerde kabiliyet imkanı artacağından yolsuzluk eylemlerinin daha sık cereyan etmesi ve yüksek menfaat temini yaratacak şekilde vuku bulması muhtemeldir. Kısacası, yolsuzluğun rahatlıkla yapılabildiği ekonomik ve sosyal iklimlerde, yönetsel gücü elinde bulunduranların kamusal kaynakları zorlanmadan ilişkili özel sektör aktörlerine aktarmaları mümkün olabilmektedir.

Özel sektör aktörleri hem fayda elde eden hem fayda sağlayanın yolsuzluk gelirini taşıyan ve aklayan hem de zorunlu olarak fayda sağlayan unsurlar olarak karşımıza çıkabilirler. Şöyle ki kamu kaynağı özel sektör aktörüne transfer edilebilir, transfer edilen kaynak içerisinde görevi kötüye kullanan kamu görevlisinin yolsuzluk kazancı saklanabilir veya özel sektör aktörünün işini yapabilmesi için kendisinden belirli bir kuruluşa (işletme, sivil toplum örgütü, vakıf vb. olabilir) kaynak transferi yapması istenebilir. Yolsuzluk eylemlerinde sıkça rastlanılan bu üç hareket tarzı; özel sektör kuruluşlarını yolsuzlukla mücadele çerçevesinde en az kamu kadar önemli bir hale getirmektedir.

1995 yılında Birleşmiş Milletler uhdesinde gerçekleştirilen "Toplumsal Kalkınma Dünya Zirvesi", yoksulluğun önlenmesi gerekliliğini ekonomik bir zorunluluk olarak kabul etmiştir. Bu hususla ilgili olarak 1999 yılı Dünya Ekonomik Forumunda Birleşmiş Milletler Genel Sekreteri Kofi Annan tarafından küresel sermaye liderlerinin bu konuda çalışmak için toplantıya davet edilmesi ve onların da 2000 yılında Birleşmiş Milletler merkezindeki toplantıya katılması neticesinde, yoksullukla mücadele resmi bir nitelik kazanmıştır. "Birleşmiş Milletler Küresel İlkeler Sözleşmesi" başta özel sektör aktörlerinin yoksullukla mücadele için adeta yoksullukla mücadelede 'ben de varım' dedikleri bir taahhüt belgesidir. Şirketlerin faaliyetlerinde yoksullukla mücadele için 4 konu başlığında 10 ilkeye uyacaklarını ve yönetim yaklaşımlarını bu 10 ilkeye göre oluşturacaklarını beyan ettikleri; bağlayıcılığı olmayan lakin Birleşmiş Milletler nezdinde resmiyet kazanmış dünyadaki en büyük sosyal sorumluluk projesidir. Sözleşmede yer alan dört konu başlı̆̆ı insan hakları, işgücü, çevre ve yolsuzlukla mücadeledir. Yolsuzlukla mücadelenin yer aldığ 10 numaralı ilke şöyle demektedir: 'İş dünyası, rüşvet ve haraç dahil her türlü yolsuzlukla savaşmalıdır'.

2021 itibariyle 60'in üzerinde ülkede yaklaşık 10.000 şirket ve 3.000'in üzerinde şirket-dışı kuruluş bu sözleşmenin imzacısı durumuna gelmiştir. Bu bahisle, Birleşmiş Milletler Küresel İlkeler Sözleşmesine katılımdaki yoğunluk; yolsuzlukla mücadelenin ekonominin temel ayaklarından birini oluşturduğunu ve aynı zamanda yoksulluğun önlenmesindeki kilit faaliyetlerin başında geldiğini ortaya koymaktadır.

Başta iş dünyası (şirketler) olmak üzere özel sektör aktörlerinin Birleşmiş Milletler Küresel İlkeler Sözleşmesi ilke 10 uyarınca yolsuzlukla savaşmaları gerekliliği hiç şüphesiz ki söz konusu kuruluşlarının paydaşlarının yolsuzlukla mücadele eylemlerinden haberdar olmalarını gerektirmektedir. Diğer bir ifadeyle, kuruluşların ilgili dönemde yolsuzlukla mücadele açısından hangi konumda olduğu paydaşlarına iletilmelidir. 


\section{Yöntem}

$\mathrm{Bu}$ çalışmada normatif araştırma yöntemi benimsenmiştir. Normatif araştırma, ilgili mevcut durumu değerlendirmek ve/veya sorunları ele almak için konuyla ilgili kuralların, ilkelerin ve doktrinlerin incelenmesi ve açıklanması sürecidir (Christiani, 2016). Bu bağlamda normatif araştırmalar, ortaya konulan görüş ve tartışmalar ışığında konuyla ilgili yazılı kurallar ve ilkeler bütününün (normlar) iyileştirilmesine katkı sunar ve uygulama teorilerinin geliştirilebilmesini temin eder. Araştırma konusuyla ilgili kurallar ve ilkeler bütününe yönelik düzenlemeler, resmi belgeler veya raporlar gibi ikincil veriler normatif araştırmada incelemeye yönelik kaynağı oluşturur.

$\mathrm{Bu}$ çalışmada esas alınan araştırma modeli, toplumun genel ihtiyaç ve beklentilerine en uygun değer ve normları değerlendirmeyi veya oluşturmayı amaçlayan normatif (kuralcı) yaklaşımdır. Bu bahisle yolsuzluk eylemleri ve yolsuzlukla mücadele olgusunun günümüzde neden muhasebenin öncelikli konuları arasında yer aldığı araştırmanın normatif incelemeye tabi tutulan temel problemi olarak belirlenmiştir. Ayrıca yolsuzluk muhasebesi kapsamındaki zorunlu açıklamaların yeterliliği bulgular ışığında tartışılmış ve normatif öneriler getirilmiştir.

Çalışmada yolsuzlukla mücadele ve yolsuzluk muhasebesi çerçevesinde yazılı uluslararası kurallar ve ilkeler dikkate alınmıştır. Bu kapsamda ülkeler tarafından kabul edilen, bağlayıcı ve resmi yasal dokümanlar normatif araştırma uhdesine dahil edilmiştir.

Çalışmada Birleşmiş Milletler Yolsuzlukla Mücadele Sözleşmesi, Birleşmiş Milletler Küresel İlkeler Sözleşmesi ve Global Raporlama İnisiyatifi tarafından yayınlanan 101, 102, 103, 205 ve 405 no'lu standartlar normatif araştırma kaynaklarını oluşturmaktadır. Dokümanlar yayımlayıcı kuruluşlar nezdinde internet üzerinden kamuya açıtır.

\section{Bulgular: Yolsuzluk Muhasebesi Açıklamaları}

Kuruluşların yolsuzluk ve yolsuzlukla mücadele konusuyla ilgili bakış açılarını yansıttıkları, iç sistemlerini ve eylemlerini raporladıkları ve bu hususta doğrudan veya dolaylı şekilde dahil oldukları olayları paydaşlarına sundukları özel alan yolsuzluk muhasebesi olarak adlandırılmakta olup; sürdürülebilirlik raporlamasının önemli bir bileşeni konumundadır.

Bu çalışmada, GRI tarafından 2016 itibariyle yayınlanan standartlar esas alınmıştır. Yolsuzluk muhasebesi kapsamında sürdürülebilirlik raporlamasına konu göstergeler 205 numaralı GRI Standardında düzenlemektedir. 'GRI 205: Yolsuzlukla Mücadele Standardı' kuruluşun konuyla ilgili yönetim yaklaşımını ve en az üç gösterge temelinde konuya özel açıklamaları yapmasını zorunlu tutmaktadır.

\subsection{Yolsuzlukla İlgili Yönetim Yaklaşımı Açıklamaları}

'GRI 205: Yolsuzlukla Mücadele Standardı' sürdürülebilirlik raporlamasında 'GRI 103: Yönetim Yaklaşımı Standardı' ile birlikte ele alınır. Bu bağlamda şayet yolsuzluk kuruluş için öncelikli konular arasındaysa GRI 103 çerçevesinde yolsuzlukla ilgili olarak kuruluşun genel yönetim yaklaşımlarının ve bileşenlerinin açıklanması gerekmektedir.

GRI sürdürülebilirlik raporlaması analitiği çerçevesinde öncelikli konuların belirlenmesinde ‘GRI 101: Temel Standardı' esas alınmaktadır. Öncelikli konular, sürdürülebilirlik raporlamasında detaylıca açıklamaya tabi tutulacak özellikli yani önemli konuları içermektedir. GRI 101'de belirtildiği üzere bir konunun önemli, yani öncelikli olabilmesi için, hem paydaş kararları üzerinde etkili olması hem de ekonomik, çevresel veya sosyal hususlarda etki göstermesi gerekmektedir (Gökten, 2018). GRI sürdürülebilirlik raporlaması analitiğinde 200, 300 ve 400 (sırasıyla ekonomik, çevresel ve sosyal etki gösteren konuları içermektedir) ana grupları dahilindeki standartların her biri (örneğin 'GRI 205: Yolsuzluk Standardı', 'GRI 304: Biyoçeşitlilik Standardı' veya 'GRI 413: Yerel Toplumlar Standardı' gibi) kuruluş için öncelikli olduğuna karar verilen konulara ilişkin minimum hangi açıklamaların yapılması gerektiğini ortaya koymaktadır. Dolayısıyla GRI sürdürülebilirlik raporlaması sistemi çerçevesinde GRI 101'e dayalı olarak öncelikli konular belirlenir, seçilen öncelikli konuyla ilgili olarak GRI 103 çerçevesinde yönetim yaklaşımı ve bileşenleri açılanır ve takiben ilgili konuya özel standart uyarınca minimum seviyede yapılması gereken açılamalar raporlanır. 


\section{S. Gökten - P. Okan Gökten 13/4 (2021) 3701-3711}

Yolsuzlukla ilgili olarak GRI tarafından yapılması tavsiye edilen yönetim yaklaşımları ve bileşenlerine yönelik açıklamalar, bunlarla sınırlı olmamak üzere aşağıda sunulmaktadır.

- Kuruluşun yolsuzlukla ilgili risk değerlendirme süreci: Yolsuzluk konusuyla ilgili olarak yönetim yaklaşımının en önemli ayaklarının başında risk değerlendirme sürecinin tesisi gelmektedir. Ortaya çıması muhtemel olan ve bu nedenle içerdiği belirsizlik sebebiyle risk yönetimi süreçlerinin önemli bir bileşimi olan yolsuzluk eylemlerinin önüne geçilebilmesi için kuruluşun yolsuzlukla mücadele kapsamında yazılı ve formel kurumsal araçlarını kullanıma hazır hale getirmiş olması önem taşımaktadır. Örneğin, kuruluşun rüşvet veya yolsuzluğa karşı sıfır tolerans politikası uyguladığını gösteren davranış kuralları kitapçığının bulunması; faaliyetlerin bu kitapçığa uygunluğunu denetleyen bir kurumsal uyumluluk departmanının teşkil edilmesi ve uyumluluk yönetim sistemi vasitasıyla yerel, bölgesel ve küresel olmak üzere tüm seviyelerdeki yöneticilerin rüşvet ve yolsuzluğa karşı aktif bir duruş sergileyerek faaliyetler henüz başlamadan bunların uyumluluğuna ilişkin red ya da onay vermesi kuruluşun yolsuzlukla ilgili risk değerlendirme sürecinin mevcudiyetinin ve etkinliğinin değerlendirilmesine olanak tanır.

- Kuruluşun çalışanlarıyla veya kuruluşun faaliyetleri veya ürünleriyle ilişkili olabilecek kişilerle ilgili çıar çatışmalarını ne şekilde tanımladığı ve yönettiği: ‘GRI 102: Genel Açıklamalar Standardı' uhdesindeki 'GRI 102-25: Çıkar Çatışmaları' göstergesi gereği kuruluşun en yüksek yönetim organına yönelik olarak çıkar çatışmasından kaçınılması için ne tür önemler alındığı belirtilmektedir. Bu gösterge çerçevesinde yapılan açıklamalar aynı zamanda yolsuzluk muhasebesi açısından da önem taşımakta ve yolsuzluğa ilişkin yönetim yaklaşımı açıklamalarından birini oluşturmaktadır. Örneğin, kuruluşun tüm yönetim kurulu üyelerinden ve üst yöneticilerinden yılda iki kez yazılı olarak dürüstlük içince hareket edeceklerine ve rüşvet veya yolsuzluğa karışmayacaklarına ilişkin taahhüt alınması bu amaca hizmet eder.

- Kuruluşun, diğger kuruluşlara yapılan hayır amaçlı bağış ve sponsorlukların (mali veya ayni olabilir) rüşvet olarak kullanılmasını ne şekilde önlediğgi: Kuruluşlar promosyon ürünleri kapsamında hediyeler verebilmekte, bağış yapabilmekte veya sponsorluk sağlayabilmektedir. Bu tür anlaşmaların rüşvet özelliği içerme ihtimali kuvvetli olabilmektedir. Çıkar ve fayda elde etme doğrultusunda kuruluş içindeki yetkili kişilerce bağış ve sponsorluk için ayrılan fonlar belirli kuruluşlara adrese teslim aktarılabilir. Bu ve benzeri kötüye kullanımları önleyen süreçlerin varlığı son derece önemlidir. Örneğin, kuruluşun tüm hediye, eğlence, bağış ve sponsorluk harcamalarının üçüncü şahıslar lehine yakından izlenmesine olanak tanıyan ek maliyet kodlama kategorilerinin kullanılması önleyici bir tedbirdir.

- Yolsuzlukla mücadeleye ilişkin iletişim ve eğitimin yöneticilere, çalışanlara, iş ortaklarına ve yolsuzluk vakaları açısından yüksek risk taşıdığı belirlenen diğer kişilere ne ölçüde uygulandığı ve uyarlandığı: Kuruluşların yazılı ve formel kurumsal araçları dışında yolsuzlukla mücadelede başvurdukları diğer bir yol, değerler ve normlar bütününü yani sözel ve informel kurumsal araçları tesis etmeye yönelik olarak gerçekleştirilen eğitimlerdir. Bu eğitimler işe yeni alınan kişilerden yöneticilere yeni iş ortaklarından tedarikçilere kadar değişik gruplara sunulmalı; bu gruplara göre özelleştirilmelidir. Örneğin, kuruluşun küresel olarak kullanıma sunulacak yeni bir yolsuzlukla mücadele e-öğrenimi seti geliştirmesi veya ilgili genel müdürün yıllık olarak yerel personelin yıl boyunca yeterli düzeyde yolsuzlukla mücadele eğitimi aldığını teyit eden bir onay belgesi sunuyor olması yolsuzlukla mücadele açısından iletişim ve eğitim faaliyetlerinin yerine getirildiğine ilişkin doneler sunar.

- Yolsuzlukla mücadele kapsamında kuruluşun kolektif eylemler gerçekleştirme kapasitesi: Yolsuzlukla mücadelede kuruluş içinden veya kuruluşa bağlı olarak dışarıdan katılımın olması veya katılımın mümkün olması, yolsuzlukla mücadelenin tüm paydaşlarla mümkün olan mertebede ortaklaşa sürdürüldüğüne ve bu bahisle yolsuzluk riskinin göreceli olarak düşüklüğüne işaret eder. Dolayısıyla ortaklaşa mücadeleyi ortaya koyacak eylemler ve/veya ortaklaşa mücadeleyi mümkün kılan sistemlerin varlığı yolsuzluk muhasebesinde yönetim yaklaşımının etkinliğinin ortaya konulabilmesi için son derece önemlidir. Örneğin, çalışanlarca tespit edilen suistimallerin gizlilikle bildirilmesini temin eden çevrimiçi bir iletişim ağının mevcudiyeti veya üçüncü tarafların olası suistimallerle ilgili şikayetlerini iletebilecekleri bir sistemin varlığı yolsuzlukla mücadelede kolektif eylemlerin varlığına işaret eder. 


\section{S. Gökten - P. Okan Gökten 13/4 (2021) 3701-3711}

\subsection{Yolsuzlukla İlgili Konuya Özel Göstergeler ve Açıklamalar}

Yolsuzluk ve yolsuzlukla mücadele hususu, kuruluş açısından öncelikli konular arasındaysa; kuruluş tarafından sürdürülebilirlik raporlamasında GRI 205 çerçevesinde yolsuzluk ve yolsuzlukla mücadele konusu özelinde minimum seviyede üç temel göstergeye dayalı olarak açıklama yapılması zaruridir. Bu göstergeler ve açıklama gereklilikleri aşağıda belirtilmektedir.

> GRI 205-1: Yolsuzlukla ilgili riskler bakımından değerlendirilen işlemler.

> GRI 205-2: Yolsuzlukla mücadele politikaları ve prosedürleri ile ilgili iletişim ve eğitim.

> GRI 205-3: Teyit edilmiş yolsuzluk vakaları ve alınan önlemler.

GRI 205-1, bir kuruluş genelinde risk değerlendirmesinin uygulanmasının kapsamını ölçer. Risk değerlendirmeleri, kuruluş içinde ve bunlarla ilgili potansiyel yolsuzluk olaylarının değerlendirilmesine yardımcı olabilir ve yolsuzlukla mücadele için politika ve prosedürlerin tasarlamasında kuruluşlara yardımcı olur. Göstergeye dayalı olarak yapılan açıklama yolsuzluğa odaklanan bir risk değerlendirmesini veya yolsuzluğun genel risk değerlendirmelerine bir risk faktörü olarak dahil edilmesini içerebilir. Burada yer alan 'işlem' terimi, kuruluş tarafından mal ve hizmetlerinin üretimi, depolanması ve/veya dağıtımı veya idari amaçlar için kullanılan tek bir yeri ifade eder. Tek bir işlem kapsamında birden fazla üretim hattı, depo veya diğer faaliyetler olabilir. Örneğin, tek bir perakende satış noktası, kuruluşun sahip olduğu veya yönettiği birkaç farklı perakende faaliyetini içerebilir.

GRI 205-1 çerçevesinde kuruluşlar aşağıda belirtilen hususlarla ilgili nitel ve nicel bilgi sunmalıdır.

a. Yolsuzlukla ilgili riskler açısından değerlendirilen işlemlerin toplam sayısı ve yüzdesi,

b. Risk değerlendirmesi yoluyla belirlenen yolsuzlukla ilgili önemli riskler.

Kuruluşlar yolsuzluk risklerini genellikle işlemler özelinde takip ederler ve değerlendirirler. Örneğin bir banka nezdindeki hesap hareketleri, uluslararası ticarette depo hareketleri, ulaşımda transfer aracının ve hattının yolcuları veya taşınan varlıklar birer işlem olarak değerlendirilmektedir. Bu işlemlerin kontrolü ve/veya onayı genellikle kurumsal uyum departmanları tarafından ele alınır. Sözgelimi uluslararası bir para transferinin gerçekleştirilmesinden önce işlemin tarafları, işlemin neden yapıldığı ve kanıtlayıcı belgeler kurumsal uyum departmanınca değerlendirmeye tabi tutulur veya uluslararası yatırım kuruluşları nezdinde açılacak bir hesap için kurumsal uyum departmanı hesap açma talebinde bulunan kişiyi inceleyerek onay verir. Kurumsal uyum departmanı teşkil edilmemiş kuruluşlar nezdinde yolsuzluk risklerinin değerlendirilmesi ve yönetilmesi iç kontrol sistemi uhdesine dahil edilir.

Yolsuzlukla mücadelenin en önemli göstergelerinden biri potansiyel yolsuzluk riskleriyle ilgili işlemlerin kurumsal uyum departmanı veya iç kontrol sistemi tarafından dönemsel olarak değerlendirilip değerlendirilmediğidir. Kuruluşlar bunun somut karşılığı olarak sürdürülebilirlik raporlamasında paydaşlarına kaç adet işlemin yolsuzluk riski açısından değerlendirmeye sokulduğunu ve bunların neticelerini bildirmek durumundadirlar.

İletişim ve eğitim, iç ve dış farkındalığı ve yolsuzlukla mücadele için gerekli kapasiteyi oluşturur. Bu bağlamda GRI 205-2 çerçevesinde kuruluşlar aşağıda belirtilen hususlarla ilgili nitel ve nicel bilgi sunmalıdır.

a. Kuruluş, yolsuzlukla mücadele edebilmek amacıyla belirli politikalar ve prosedürler geliştirmekte ve bunları ilgili birim üyelerine bildirmektedir. Söz konusu üyelerin bölgelere göre ayrılmış toplam sayılarının ve yüzdelerinin raporlanması gerekmektedir.

b. Yolsuzlukla mücadele amacıyla geliştirilen politikalar ve prosedürler, kuruluş çalışanlarına iletilmektedir. Bu çalışanların, çalışan kategorisine ve bölgeye göre ayrıştırılmış olacak şekilde toplam sayısının ve yüzdesinin raporlanması önemlidir.

c. Yolsuzluğu önlemek amacıyla geliştirilen politika ve prosedürler, kuruluşun iş ortaklarını ilgilendirmektedir. Söz konusu iş ortaklarının, iş ortaklığı türüne ve bölgeye göre ayrıştırılmış olacak şekilde toplam sayılarının ve yüzdelerinin raporlarda yer alması gerekmektedir. 


\section{S. Gökten - P. Okan Gökten 13/4 (2021) 3701-3711}

d. Kuruluşun yolsuzlukla mücadeleyi sağlamaya yönelik eğitim almış yönetim kurulu üyelerinin bulunması durumunda, bu üyelerin bölgelere göre ayrılmış toplam sayılarının ve yüzdelerinin raporlanmasi gerekmektedir.

e. Yolsuzlukla mücadelenin sağlanabilmesi için eğitim almış olan kuruluş çalışanlarının, çalışan kategorisine ve bölgelere ayrıştırılmış şekilde toplam sayısının ve yüzdesinin raporlanması gerekmektedir.

GRI 205-2 kapsamında gerekli bilgilerin sunulmasında 'GRI 405: Çeşitlilik ve Fırsat Eşitliği Standardı' uhdesinde 405-1 numaralı göstergeden yararlanılması tavsiye edilmektedir. GRI 405-1 uyarınca kuruluş, yönetim organlarını (yönetim kurulu, yönetim komitesi veya benzer nitelikteki organları), yönetim organlarını oluşturan bireyleri ve/veya bu yönetim organlarına bağlı olarak çalışanların toplam sayısını ve yönetim organları dışındaki çalışan sayılarını raporlar. Dolayısıyla, GRI 405-1 kapsamında sunulan bu bilgiler yolsuzlukla mücadele kapsamındaki iletişim ve eğitim hususlarının belirtilmesinde nicel olarak kilit rol oynar.

Paydaşların karar süreçleri açısından yolsuzluk olaylarının ve kuruluşun yolsuzluk olayları içerisindeki konumunun bilinmesi önemlidir. Bu bahisle yolsuzlukla ilgili kamuya açık davalar, soruşturmalar veya kovuşturmalar hakkındaki bilgiler sürdürülebilirlik raporlamasında yer almalıdır. GRI 205-3 çerçevesinde kuruluşlar aşağıda belirtilen hususlarla ilgili nitel ve nicel bilgi sunmalıdır.

a. Teyit edilmiş olan yolsuzluk olaylarının toplam sayısının ve niteliğinin raporlanması gerekmektedir.

b. Çalışanların yapmış oldukları yolsuzluk faaliyetlerinden ötürü işten çıkarıldıkları ya da cezalandırıldıkları olayların toplam sayısının raporlanması önemlidir.

c. Yolsuzluk faaliyetlerinden kaynaklı olarak iş ortaklıkları ile önceden yapılmış olan sözleşmelerin feshedilmesi ya da yenilenmemesi gibi durumlar söz konusu olabilir. Bunların toplam sayısının raporlanması gerekmektedir.

d. Kurumun bizzat kendisi ya da çalışanları aleyhine yolsuzluk faaliyetlerinden kaynaklı olarak açılmış kamu davalarının olması durumunda söz konusu davalara yönelik her türlü bilginin sonuçlarıyla birlikte raporlanması gerekmektedir.

GRI 205-3 kuruluşların şeffaf olarak yolsuzluk eylemleriyle ilgili inceleme konusu edilen olayları istatistiki olarak raporladıkları ve sonuçları ifade ettikleri kısımdır. Örneğin bir kuruluş bu gösterge gereği görevi kötüye kullanma iddiasıyla ilgili 50 bildirim aldığını; bunlardan 40 tanesinin iç soruşturma sürecini başlattığını; 7 soruşturmada kesin olarak pasif rüşvet vakası (çalışanların tedarikçilerden komisyon ödemesi istemesi) tespit edildiğini ve bunun sonucunda ilgili çalışanların işlerine son verildiğini raporlayabilir. Anlaşılabileceği gibi, GRI 205-3 gereği bu denli net istatistiki bilgi verebilen bir kuruluşun hiç şüphesiz ki yolsuzlukla mücadele özelinde işlerlik kazanmış bir iç kontrol sistemi ve denetim mekanizması olduğu açıktır.

\section{Sonuç ve Tartışma}

Yolsuzlukla mücadele, toplumların yaşam kalitelerinin optimizasyonuna yönelik olarak uluslararası düzeyde sürdürülebilir kalkınmanın temini açısından giderek önem kazanan bir unsur haline gelmiştir. Kurumsal kalitenin kalkınma üzerindeki etkisi dikkate alındığında gerek şeffaflık gerekse de hesap verebilirlik temelinde yolsuzlukla mücadele olgusu, başta şirketler olmak üzere özel sektör aktörlerinin yolsuzlukla mücadele eylemleri hakkında paydaşlarına açıklama yapmasını gerektiren önemli bir finansal olmayan bilgi niteliği kazanmıştır. Gerek Birleşmiş Milletler Yolsuzlukla Mücadele Sözleşmesi gerekse de Birleşmiş Milletler Küresel İlkeler Sözleşmesi, yolsuzlukla mücadele olgusunun sürdürülebilir kalkınmanın sağlanmasında ele alınması gereken bileşenlerden biri olduğunu teyit etmektedir.

Kuruluşların sürdürülebilirlik muhasebesi ve raporlaması kapsamında spesifik olarak yolsuzlukla mücadele hususundaki durumunu, eylemlerini ve katkısını anlamlı finansal olmayan bilgilere dönüştürerek paydaşlarına iletmelerini sağlamayı hedef alan yolsuzluk muhasebesi ve gerekli açıklamalar, Global Raporlama İnisiyatifi (GRI) 205 no'lu Yolsuzlukla Mücadele Standardı dahilinde yer almaktadır. GRI 205 no'lu Standart kuruluşların yolsuzlukla mücadele hususuyla ilgili yönetim yaklaşımlarını (GRI 103 no'lu Standart çerçevesinde) ve minimum üç gösterge temelinde (GRI 205-1, GRI 205-2 ve GRI 205-3) sırasıyla (1) yolsuzlukla ilgili riskler bakımından değerlendirilen işlemlerini, (2) yolsuzlukla mücadele politikaları ve prosedürleri ile ilgili iletişim ve eğitimlerini ve (3) teyit edilmiş yolsuzluk vakalarını ve alınan önlemleri raporlamalarını zorunlu tutmaktadır. 


\section{S. Gökten - P. Okan Gökten 13/4 (2021) 3701-3711}

Normatif inceleme sonucunda GRI Standartları bünyesinde yer verilen yolsuzlukla mücadele göstergelerinin paydaşlara nitelik açısından yoğun bilgi aktarım imkanı sağladı̆̆ı değerlendirilmektedir. Ayrıca göstergelerde yer alan nicelik gerekliliği yolsuzluk vakalarının sayısı, eğitim alan personel sayısı, soruşturma sayısı, şikayet sayısı gibi sayısal bilgilerin verilmesini zorunlu tutmaktadır. Bu açıdan GRI 205 çerçevesinde yolsuzlukla mücadele hususunda paydaşlara faydalı finansal olmayan bilgiler sunulabilmesinin temin edilmeye çalışıldığı anlaşılmaktadır. Dolayısıyla tüm bu doneler yolsuzluk eylemleri ve yolsuzlukla mücadele olgusunun muhasebenin önemli konuları arasında yer aldığını teyit etmektedir.

Buna karşın GRI 205 göstergelerinin, raporlama uygulaması açısından kuruluşlara esneklik tanıdığı değerlendirilmektedir. Kuruluşlar bu göstergelere göre çok detaylı bilgi verebilecekleri gibi, bilgi düzeyini düşük de tutabilirler. Diğer bir ifadeyle kurumsal uyum departmanının varlığını, açılan soruşturma adedini ve ilişik kesme durumunu, verilen eğitimleri ve klasik bir gösterge söylemi olarak Birleşmiş Milletler Küresel İlkeler Sözleşmesi'nin 10 numaralı ilkesine bağlılığı vurgulamak suretiyle raporlamanın yolsuzluk muhasebesi ayağını sonlandırabilirler. Dolayısıyla GRI 205 göstergelerinin verilen bilgilerin nitelik ve nicelik çerçevesinin daha kalın çizgilerle çizilecek şekilde revize edilmesi gerektiği değerlendirilmektedir.

Ayrıca, bu çalışmada da belirtildiği üzere büyük hacimli yolsuzluk eylemlerinde bir taraf kamu iken diğer tarafın özel sektör aktörü olma durumu sıklıkla karşılaşılan bir vakadır. Dolayısıyla GRI 205 uhdesine kamu ile yapılan anlaşmalarda yolsuzlukla mücadele politikaları ve prosedürleri başlıklı bir göstergenin eklenmesinin gerekli olduğu değerlendirilmektedir. Bu sayede özellikle kamuyla yapılan işlerin (imzalanan sözleşmelerin) hacmi, çalışılan kamu birimleri, rakipler, bu sözleşmelere özel eğitim ve ilişkiler, bu işlerle ilgili açılan soruşturmalar ve/veya bildirilen vakalar raporlanarak paydaşlara iletilebilecektir.

\section{Kaynaklar}

Aktan, C. C. (2001). Yolsuzlukla mücadele stratejileri, Ankara, Hak-iş yayınları.

Bardhan, P. (1997). Corruption and development: A review of issues. J. Econ. Lit., 35, 1320-1346.

Besley, T., \& McLaren, J. (1993). Taxes and bribery: the role of wage incentives. The economic journal, 103(416), 119-141.

Christiani, T. A. (2016). Normative and Empirical Research Methods: Their Usefulness and Relevance in the Study of Law as an Object. Procedia-Social and Behavioral Sciences, 219, 201-207.

Cragg, W.,\& Woof, W. (2002). The U. S. Foreign Corrupt Practices Act: A Study of Its Effectiveness. Business and Society Review, 107(1), 98-144.

Euronews, (2021). Dünya Yolsuzlukla Mücadele Günü, https://tr.euronews.com/2019/12/09/dunyayolsuzlukla-mucadele-gunu-her-yil-1-trilyon-dolar-rusvet-veriliyor (Erişim Tarihi: 10.02.2021).

Gökten, S. (2018). Ekonomik Kalkınma Teorisi ile Muhasebedeki Paradigma Kayması Arasındaki Etkileşim: Saptanan Ayak İzleri ve Çıkarımlar. İşletme Araştırmaları Dergisi, 10(3), 848-873.

Habib, M., \& Zurawicki, L. (2002). Corruption and foreign direct investment. J. Int. Bus. Stud., 33, 291-307.

Jain, A. (2001). Corruption: A review. J. Econ. Surv., 15, 71-121.

Luo, Y. (2011). Strategic responses to perceived corruption in an emerging market: Lessons from MNEs investing in China. Bus. Soc., 50, 350-387.

Mauro, P. (1998). Corruption and the composition of government expenditure. J. Public Econ., 69, 263-279.

Morishima, M. (1982). Why has Japan' succeeded'?: Western technology and the Japanese ethos. Cambridge University Press.

North, D. C. (1981). Structure and change in economic history. W.W. Norton \&Co, NewYork.

North, D.C.,\& Thomas, R. P. (1973). The rise of the western world: A new economic history. Cambridge University Press.

Okan Gökten, P. (2018). “Hileli eylemlerin nedenlerine ilişkin paradigma değişimleri: Üçgen, elmas ve diğerleri", İşletme Araştırmaları Dergisi, 10(3), 655-669. 


\section{S. Gökten - P. Okan Gökten 13/4 (2021) 3701-3711}

Rijckeghem, C. V., \& Weder, B. (1997). Corruption and the rate of temptation: do low wages in the civil service cause corruption?. IMF Working Papers, 97, 73.

Rodriguez, P., Siegel, D. S., Hillman, A., \& Eden, L. (2006). Three lenses on the multinational enterprise: Politics, corruption, and corporate social responsibility.J. Int. Bus. Stud., 37, 733-746.

Ronen, S.,\&Shenkar, O. (1985). Clustering countries on attitudinal dimensions: A review and synthesis. Academy of management Review, 10(3), 435-454.

Sanyal, R. (2005). Determinants of bribery in international business: The cultural and economic factors. J. Bus. Ethics, 59, 139-145.

Svensson, J. (2005). Eight questions about corruption. J. Econ. Perspect., 19, 19-42.

Tanzi, V. (1995). Corruption: arm's-length relationships and market, G. Fiorentini, \& S. Peltzman (Ed.), The economics of organized crime, Cambridge, Cambridge University Press. 161-180.

UNCAC (2021). United Nations Convention against Corruption. https://www.unodc.org/unodc/en/corruption/uncac.html (Erişim tarihi: 15.11.2021).

Wolfe, D. T. \& Hermanson, D. R. (2004). “The fraud diamond: Considering the four elements of fraud”, CPA Journal, 74 (12), 38-42. 